\title{
CITRA PEREMPUAN DALAM NOVEL BIDADARI TERAKHIR KARYA AGNES DAVONAR
}

\author{
Cici Chyntia Dewi, ${ }^{1}$ Hilaluddin Hanafi, ${ }^{2}$ Yunus $^{3}$ \\ pbsi.fkip.uho@gmail.com \\ 1,2,3, Jurusan Pendidikan Bahasa dan Sastra Indonesia, \\ Fakultas Keguruan dan Ilmu Pendidikan, Universitas Halu Oleo \\ Kampus Hijau Bumi Tridharma Anduonohu, Kendari, Indonesia
}

\begin{abstract}
Abstrak
Tujuan penelitian ini adalah untuk mendeskripsikan citra perempuan dalam novel Bidadari Terakhir karya Agnes Davonar. Metode penelitian yang digunakan dalam penelitian ini adalah metode deskriptif kualitatif. Jenis penelitian ini adalah kualitatif yang tidak menggunakan prinsip statistik, melainkan berpedoman pada teori-teori sastra yang berkaitan dengan penelitian. Manfaat yang dapat diperoleh dari penelitian ini, yaitu menambah pengetahuan bagi penulis dan pembaca. Data yang digunakan dalam penelitian ini adalah data tertulis yaitu berupa teks novel yang berhubungan dengan citra perempuan dalam novel Bidadari Terakhir karya Agnes Davonar. Sumber data dalam penelitian ini adalah novel Bidadari Terakhir karya Agnes Davonar yang diterbitkan oleh Intibook Publisher cetakan pertama 2013, dengan jumlah 163 halaman. Teknik yang digunakan untuk mengumpulkan data dalam penelitian ini adalah teknik baca catat. Data dalam penelitian ini dianalisis dengan menggunakan kritik sastra feminis dengan melihat isi dan tujuan yang tersirat di dalam karya sastra itu sendiri dengan menginterpretasikan tentang citra perempuan. Dari hasil penelitian ini penulis menyimpulkan bahwa novel Bidadari Terakhir karya Agnes Davonar mencerminkan citra perempuan bagi pembaca yaitu, pertama citra perempuan sebagai individu yang meliputi citra perempuan secara fisik dan psikis, kedua citra perempuan sebagai anggota keluarga yang mencerminkan citra perempuan sebagai seorang anak dan citra perempuan sebagai ibu rumah tangga, ketiga citra perempuan dalam masyarakat berkaitan dengan hubungan antarpribadi dan pribadi dengan masyarakat, dan keempat citra perempuan dalam bidang pendidikan dan kelima citra perempuan dalam bidang ekonomi yang mengharuskan perempuan mampu mencari nafkah untuk memenuhi kebutuhan hidupnya.
\end{abstract}

Kata Kunci: citra; perempuan; novel 


\section{PENDAHULUAN}

\subsection{Latar Belakang}

Citra perempuan adalah penggambaran atau cerminan sosok perempuan yang merupakan makhluk yang sangat menarik. Citra perempuan sangat berkaitan erat dengan karya sastra, secara gamblang banyak karya sastra yang menuliskan cerita tentang citra perempuan sebab, perempuan merupakan aspek yang unik dan menarik untuk dibahas dan ditulis dalam karya sastra. Karya sastra selalu menyediakan ruang terbuka pada setiap objek yang diperbincangkan salah satunya melalui novel. Novel merupakan salah satu di antara bentuk sastra yang paling peka terhadap cerminan dan pencitraan bagi masyarakat. Karya sastra banyak mengungkapkan persoalan kehidupan. Peristiwa-peristiwa yang terjadi dalam kehidupan, baik yang menyenangkan maupun yang menyedihkan terungkap dalam karya sastra. Perempuan dan beberapa sifat khasnya selalu menjadi pembahasan yang menarik, karena sifat yang terdapat pada diri perempuan masih berupa rahasia yang menyebabkan para ahli maupun pujangga tertarik untuk membahasnya.

Berbagai citra diri yang ditampilkan oleh seorang perempuan juga menunjukkan bahwa selain sebagai seorang pribadi, ia juga merupakan makhluk sosial yang membutuhkan orang lain dalam kehidupannya.

Citra perempuan merupakan wujud gambaran mental spiritual dan tingkah laku keseharian yang terekspresi oleh perempuan dalam berbagai aspeknya yaitu aspek fisik dan psikis sebagai citra diri perempuan serta aspek keluarga dan masyarakat sebagai citra sosial. (Sugihastuti, 2000:7). Dari pendapat tersebut, realitas perempuan pada masa kini bisa menanamkan cita-cita setinggi mungkin dan mampu untuk meraihnya. Pada dasarnya perempuan masa kini tidak hanya sebagai ibu rumah tangga yang harus melayani suami dan mengurus anak-anaknya.

Novel Bidadari Terakhir di terbitkan di Jakarta oleh Intibook Publisher, cetakan pertama pada Maret tahun 2013 dengan jumlah halaman sebanyak 163 halaman. Novel ini mendeskripsikan tentang kehidupan perempuan di dunia malam demi menunjang kebutuhan hidup dan ekonomi keluarga. Lebih dari itu, novel ini memotivasi para perempuan dan generasi muda pada umumnya untuk meraih kesuksesan dengan bekerja keras, ulet dan rendah hati dangan menebar kebaikan secara universal.

Dalam novel Bidadari Terakhir mengisahkan tentang seorang gadis cantik yang bernama Evaria yang akrab di sapa Eva. Eva adalah seorang perempuan yang tinggal di sebuah permukiman kumuh di kota Balikpapan bersama kedua orang tuanya. Eva bukanlah gadis biasa yang senang menghamburhamburkan uang untuk berfoya-foya, ia justru bekerja dan mengumpulkan uang dengan susah payah demi memenuhi kebutuhan ekonomi keluarga meskipun harus bekerja sebagai wanita tuna susila di salah satu club malam yang terletak di sudut kota Balikpapan. Wajah cantik dan tubuh yang mungil tak serta merta membuat Eva disenangi oleh orang-orang sekitarnya karena mereka mengetahui pekerjaan apa yang di lakukan oleh eva, bahkan tidak sedikit orang yang menghina dan mencaci maki dirinya sebagai wanita tuna susila karena pekerjaan yang dilakoninya di luar sepengetahuan keluarganya. Bahkan eva harus tetap bekerja meskipun dia tahu tidak akan ada pengunjung yang berminat dengan wajah cantik dan tubuh mungilnya lagi akibat penyakit sivilis yang di deritanya kini ia justru kehilangan pelanggan dan susah mendapatkan uang untuk memenuhi kebutuhan hidupnya dan membantu biaya pengobatan ibunya yang sedang sakit.

\subsection{Rumusan Masalah}

Berdasarkan latar belakang, masalah dalam penelitian ini yaitu;

a. Bagaimanakah citra perempuan dari aspek fisik, psikis, soal masyarakat dan ekonomi yang terkandung dalam novel Bidadari Terakhir Karya Agenes Davonar?

b. Bagaimanakah nilai pendidikan dari citra perempuan dalam novel bidadari terakhir karya Agnes Davonar?

\subsection{Tujuan Penelitian}

Tujuan penelitian ini adalah untuk mendeskripsikan citra perempuan dalam novel Bidadari Terakhir Karya Agnes Davonar dan mengetahui nilai-nilai pendidikan yang terkandung dalam novel Bidadari Terakhir karya Agnes Davonar.

\subsection{Manfaat Penelitian}

Manfaat yang ingin dicapai dalam penelitian ini adalah sebagai berikut.

a. Bahan masukan dalam upaya pengembangan kritik sastra Indonesia, 
khususnya kajian aspek feminisme dalam novel Indonesia modern

b. Bahan masukan dalam pengembangan apresiasi sastra Indonesia baik dunia pendidikan pada khususnya maupun di kalangan masyarakat pada umumnya.

c. Sumbangan pemikiran tentang unsur feminisme bagi para peneliti selanjutnya.

d. Sumbangan pemikiran dalam usaha pemberdayaan perempuan secara utuh tanpa mencederai kodrat perempuan itu sendiri.

\section{KAJIAN PUSTAKA}

\subsection{Pengertian Sastra}

Pradopo (dalam Wicaksono, 20014:

11) menyatakan bahwa karya sastra adalah karya seni, suatu karya yang menghendaki kreatifitas dan menghendaki imajinatif. Karya sastra imajinatif karena hasil angan-angan pengarang merupakan penemuan-penemuan baru, kemudian penemuan itu disusun kedalam suatu sistem dengan kekuatan imajinasi hingga terciptalah dunia baru yang sebelumnya belum ada.

\subsection{Pengertian Novel}

Menurut Nurgiyantoro (2015 : 18) novel adalah suatu cerita yang bermain dalam dunia manusia dan benda yang ada di sekitar kita, tidak mendalam, lebih banyak melukiskan suatu saat dari kehidupan seseorang, dan lebih mengenai sesuatu episode. Novel sebagai sebuah karya fiksi menawarkan sebuah dunia, dunia yang berisi model kehidupan yang di idealkan, dunia imajinatif, yang dibangun melalui berbagai unsur intrinsiknya seperti peristiwa, plot, tokoh (dan penokohan), latar, sudut pandang dan lain-lain yang kesemuanya juga bersifat imajinatif.

\subsubsection{Pengertian Pendidikan}

Menurut Wibowo (2013: 1) Pendidikan idealnya merupakan sarana humanisasi bagi anak didik. Itu karena pendidikan memberikan ruang pengajaran etika moral, dan segenap aturan luhur yang membimbing anak didik mencapai humanisasi. Melalui proses itu, anak didik menjadi terbimbing, tercerahkan, sementara tabir ketidaktahuannya terbuka lebarlebar sehingga mereka mampu mengikis bahkan meniadakan aspek-aspek yang mendorong kearah dehumanisasi.

\subsubsection{Pengertian Karakter}

Menurut Kemendiknas (dalam Wibowo, 2013: 13), karakter adalah watak, tabit, akhlak, atau kepribadian seseorang yang terbentuk dari hasil internalisasi berbagai kebajikan (virtues), yang diyakini dan digunakan sebagai landasan untuk cara pandang, berpikir, bersikap, dan bertindak.

\subsection{Unsur-unsur Novel}

Unsur intrinsik novel terdiri dari beberapa sub. Beberapa unsur tersebut adalah tema, tokoh dan penokohan, alur, gaya bahasa,setting atau latar cerita, sudut pandang dan juga amanat. Tema adalah pokok permasalahan yang digunakan untuk membentuk cerita dalam novel. Tokoh dan penokohan merupakan pemberian karakter atau watak pada setiap tokoh dalam novel tersebut. Sedangkan alur merupakan rentetan peristiwa dari jalannya novel.

Unsur ekstrinsik adalah unsur-unsur yang berada diluar karya sastra. Namun secara tidak langsung mempengaruhi bangun atau sistem organisme karya sastra. Menurut (Nurgiyantoro 2015: 31) unsur ekstrinsik adalah unsur yang berada diluar teks fiksi yang bersangkutan, tetapi mempunyai pengaruh terhadap bangun cerita yang dikisahkan langsung atau tidak langsung. Hal-hal yang dapat dikategorikan kedalam hal ini adalah jati diri pengarang yang mempunyai idiologi, pandangan hidup dan way of life bangsanya, kondisi kehidupan sosial-budaya masyarakat yang dijadikan latar cerita dan lain-lain.

\subsection{Nilai Pendidikan}

Nilai pendidikan adalah sesuatu yang diyakini kebenarannya dan mendorong orang untuk berbuat positif di dalam kehidupannya sendiri atau bermasyarakat. Sehingga nilai pendidikan dalam karya sastra disini yang dimaksud adalah nilai-nilai yang bertujuan mendidik seseorang atau individu agar menjadi manusia yang baik dalam arti berpendidikan.

Nilai pendidikan dalam karya sastra dibedakan atas empat macam yaitu: nilai moral, nilai kebenaran, nilai keindahan, dan nilai religius.

1. Nilai moral

Moral adalah ajaran tentang baik buruk yang diterima mengenai perbuatan, sikap, berkewajiban dan sebagainya. Moral dapat pula disebut dengan akhlak budi pekerti dan susila. 
Untuk mencapai keutamaan seorang anak harus memiliki sikap sebagai berikut:

a. Suka menolong

Suka menolong adalah kebiasaan menolong dan membantu orang lain. Kebiasaan menolong ini juga merupakan suatu perilaku yang dapat ditanamkan dengan selalu siap mengulurkan tangan dan dengan cara aktif mencari kesempatan untuk menyumbang.

b. Keteguhan hati dan Komitmen

Keteguhan hati dan komitmen adalah pendidikan moral yang baik untuk membentuk mental yang positif. Komitmen membuat seseorang bertahan dalam mencapai cita-cita, pekerjaan seseorang dan orang lain. Komitmen merupakan janji yang dipegang teguh terhadap keyakinan dan memberi dukungan serta setia kepada keluarga dan teman. Keteguhan hati dapat membuat seseorang menncapai citacitanya.

c. Kepedulian dan empati

Kepedulian dan empati didasarkan pada pemahaman perasaan diri sendiri dan memahami orang lain. Kepedulian dan empati adalah cara kita menanggapi perasaan, pikiran, dan pengalaman orang lain karena kita secara alami merasakan kepedulian terahadap sesama agar berupaya mengenali pribadi orang lain dan keinginan membantu orang lain yang sedang dalam keadaan susah. Melalui empati, seseorang mengenali rasa kemanusiaan terhadap diri sendiri ataupun orang lain.

d. Tanggung jawab

Tanggung jawab adalah perilaku yang menentukan seseorang bereaksi terhadap situasi setiap hari yang memerlukan beberapa keputusan.

\subsection{Feminisme}

Menurut Moeliono, feminisme adalah gerakan kaum perempuan yang menuntut persamaan hak sepenuhnya antara kaum perempuan dan laki-laki. Sedangkan menurut Geofe, feminisme adalah teori tentang persamaan antara laki-laki dan perempuan di bidang politik, ekonomi, dan sosial, atau kegiatan terorganisasi yang memperjuangkan hak-hak serta kepentingan perempuan (Sugihastuti, 2015: 18).

\subsection{Citra Perempuan}

Citra perempuan sebagai semua wujud gambaran mental, spiritual dan tingkah laku keseharian perempuan yang menunjukkan "wajah" dan ciri khas perempuan. Teori yang paling dekat untuk mengungkapkan citra perempuan adalah feminis. citra perempuan dalam aspek sosial disederhanakan kedalam dua peran, yaitu peran perempuan dalam keluarga dan peran perempuan dalam masyarakat.

\section{Citra Perempuan Indonesia}

Djajanegara (2010:118) menjelaskan Perkembangan kaum wanita Indonesia tidak jauh berbeda dari perkembangan wanita dunia barat. Hanya disana usaha-usaha memberdayakan wanita dilakukan jauh lebih awal dari pada Indonesia, yaitu sekitar tahun 1850-an. Pada waktu itu perempuan Amerika juga tidak diberi kesempatan untuk mendapatkan pendidikan yang tinggi.

\subsection{Citra Perempuan dalam \\ Feminisme}

Djajanegara (2003: 5) menjelaskan bahwa bidang citra perempuan dibagi menjadi beberapa bagian yaitu: citra perempuan di bidang keluarga citra perempuan di bidang pendidikan, citra perempuan di bidang ekonomi, dan citra perempuandi bidang sosial.

\subsection{Citra Perempuan Sebagai \\ Individu}

Sebagai makhluk individu, selain terbentuk dari aspek fisik, perempuan juga terbangun oleh aspek psikis. Ditinjau dari aspek psikisnya, perempuan merupakan makhluk psikologis makhluk yang berfikir, berperasaan dan beraspirasi (Sugihastuti dalam Udu, 2009: 92). Dengan melihat dari dua aspek tersebut akan terlihat dengan jelas keutuhan individu seorang perempuan. Pembicaraan mengenai aspek psikis perempuan akan membawa kita pada pemahaman bahwa perkembangan kehidupan perempuan terbangun oleh berbagai faktor, termasuk didalamnya aturan-aturan, tata nilai, adat, dan budaya masyarakat yang secara langsung atau tidak langsung membangun dan mengkonstruksi pikiran dan perasaan perempuan.

\subsection{Citra Sosial Perempuan}

Citra sosial wanita merupakan citra wanita yang erat hubungannya dengan norma dan sistem nilai yang berlaku dalam satu kelompok masyarakat, tempat wanita menjadi anggota dan berhasrat mengadakan hubungan antarmanusia. Kelompok masyarakat itu adalah kelompok keluarga dan kelompok masyarakat luas. Dalam keluarga, misalnya wanita berperan sebagai istri, ibu, dan sebagai anggota keluarga yang 
masing-masing peran mendatangkan konsekuensi sikap sosial,yaitu satu dengan lainnya saling berkaitan.

\section{METODE PENELITIAN}

\subsection{Jenis dan Metode Penelitian}

\subsubsection{Jenis Penelitian}

Jenis penelitian yang digunakan dalam penelitian ini adalah penelitian kepustakaan (library research). Dikatakan penelitian kepustakaan karena kajian berupa data tertulis dan kegiatan dalam mencari, mengumpulkan, dan mendapatkan data-data yang diperlukan, umumnya dengan cara menelaah dan menganalisis citra perempuan dalam novel Bidadari Terakhir Karya Agnes Davonar.

\subsubsection{Metode Penelitian}

Metode yang digunakan dalam penelitian ini adalah metode deskriptif kualitatif. Dikatakan deskriptif karena dalam penelitian ini mendeskripsikan data berdasarkan kenyataankenyataan secara objektif, sesuai dengan data yang ditemukan. Dikatakan kualitatif karena dalam penjelasan konsep-konsep yang berkaitan satu sama lain dilakukan dengan menggunakan kata-kata atau kalimat, bukan menggunakan angka-angka statistik.

\subsection{Data dan Sumber Data \\ 3.2.1 Data Penelitian}

Data yang digunakan dalam penelitian ini adalah data tertulis berupa teks novel, yang memuat citra perempuan dalam novel Bidadari Terakhir Karya Agnes Davonar.

\subsubsection{Sumber Data}

Sumber data dalam penelitian ini adalah sumber data tertulis dalam novel Bidadari Terakhir karya Agnes Davonar yang diterbitkan oleh Intibook Publisher cetakan pertama tahun 2013 dan terdiri dari 163 halaman. Dalam hal ini, peneliti tidak terlepas dari buku-buku atau literatur yang dianggap menunjang dan relevan dalam penelitian ini.

\subsection{Teknik Pengumpulan Data}

Teknik pengumpulan data yang digunakan dalam penelitian ini adalah teknik pustaka, baca dan catat yang dilaksanakan dengan langkah-langkah sebagai berikut:

a. Peneliti mencari, mengumpulkan, membaca dan mempelajari sumber-sumber tertulis berupa buku, artikel, yang berkaitan dengan sastra feminis atau citra perempuan untuk memperoleh data.

b. Peneliti melakukan pencatatan terhadap data yang ditemukan dalam subjek penelitian yang sesuai dengan tujuan penelitian yaitu citra perempuan.

\subsection{Teknik Analisis Data}

Data penelitian ini dianalisis berdasarkan pendekatan feminisme. Yaitu suatu pendekatan dalam studi sastra yang mengarahkan fokus analisis pada perempuan. Analisis data dilakukan dengan langkah-langkah sebagai berikut:

a. Mengidentifikasi data yang berhubungan dengan peran perempuan yang terdapat dalam novel Bidadari Terakhir karya Agnes Davonar.

b. Klasifikasi, yaitu mengklasifikasikan (mengelompokan data) peran perempuan berdasarkan jenis citranya.

c. Analisis data, yaitu menganalisis data yang menjadi objek dengan kritik sastra feminis.

d. Interpretasi data, yaitu memberikan gambaran secara umum tentang hasil penelitian yang diperoleh, hal tersebut tampak pada kesimpulan penelitian.

\section{HASIL PENELITIAN DAN PEMBAHASAN \\ 4.1 Deskripsi Hasil Penelitian}

Hasil penelitian dalam pembahasan novel Bidadari Terakhir menunjukkan beberapa aspek citra perempuan yang menarik untuk dikaji diantaranya, yaitu citra perempuan sebagai individu, citra perempuan sebagai anggota keluarga, citra perempuan dalam masyarakat,citra perempuan dalam bidang pendidikan dan citra perempuan dalam bidang ekonomi.

\subsection{Deskripsi Citra Perempuan dalam Novel Bidadari Terakhir Karya Agnes Davonar 4.2.1 Citra Perempuan Sebagai Individu}

Gambaran perempuan yang sadar akan keindividualitasnya dapat dicermati dalam novel Bidadari Terakhir karya Agnes Davonar sebagai makhluk individu, perempuan terbentuk dari aspek fisik dan psikis, dimana kedua aspek ini dapat mengantarkan kita untuk memahami perempuan secara utuh. 


\subsubsection{Citra Perempuan secara \\ Fisik}

Dari gambaran mengenai citra fisik perempuan diharapkan dapat membangkitkan semangat perempuan dalam mengarungi kehidupan keluarga. Untuk representasi citra perempuan dalam novel Bidadari terakhir karya Agnes Davonar bila dilihat dari aspek fisik dapat dilihat pada tokoh utama Eva. Gambaran tokoh Eva dari segi fisik dapat dilihat dari segi penampilan (penampilan yang dapat dilihat secara kasat mata) mulai dari gaya berpakaian, postur tubuh, dan penampilan secara keseluruhan yang merupakan gambaran nyata bisa dilihat dari luar. Citra perempuan secara fisik dari gaya berpakaian dalam novel Bidadari Terakhir ditunjukkan pada kutipan data 1 berikut.

"Beberapa perempuan yang tadinya berbaris menyambut tamu yang datang mulai menghilang dan menyisakan satu perempuan yang tampak begitu kesal sambil melempar rokoknya ke lantai dan menginjaknya dengan hak tinggi yang dia kenakan. Hati gue berdebar kencang memandang wajahnya, dia terlihat begitu cantik dengan rambut sepundak, kulitnya putih mulus dan tidak ada yang bisa gue bayangkan baru kali ini gue duduk dengan seorang perempuan yang sebenarnya cantik akan tetapi ia adalah seorang perempuan penggoda." (Agnes, 2013:7)

Kutipan data satu diatas menggambarkan keadaan fisik tokoh mengenakan sepatu hak tinggi dengan wajah cantik, rambut sepundak dan kulit putihnya yang mulus dengan sepuntung rokok yang telah di injaknya menunjukkan bahwa Eva adalah seorang wanita penghibur yang bekerja menjajakan dirinya kepada setiap laki-laki yang datang demi mendapatkan uang.

Citra perempuan secara fisik tokoh utama yang digambarkan tidak berdaya juga terdapat pada data 3 dalam kutipan berikut.

"Dokter menarik napas pelan. Lalu dia membenarkan kaca matanya yang sejatinya tidak pernah berubah posisinya. Sebenarnya yang bikin keadaan dia tambah buruk bukan cuma gara-gara sakit kuningnya, tapi pacar anda mengidap sifilis stadium tiga. Maaf saya harus menyampaikan hal ini. Sayang sekali, penyakitnya terlambat ditangani. Dia sudah mengalami apa yang disebut dengan sifilis laten. "(Agnes, 2013:109)

Kutipan dari data dua dan tiga tersebut menjelaskan bahwa kondisi fisik Eva tidak kelihatan sehat. Kondisi tubuhnya sangat drop. Kondisi fisiknya yang drop ini diakibatkan oleh penyakit sifilis yang ia derita, ia harus menjalani perawatan dan harus disuntik setiap harinya. Meskipun kondisinya drop, Eva tetap menjadi wanita yang periang karena ia takut jika suatu hari nanti meninggalkan dunia ini ia tidak bisa lagi menikmati keceriaan seperti yang ia rasakan di dunia. Tubuhnya yang lemah kadang harus membuat anggota badannya yang lain ikut menjadi korban.

\subsubsection{Citra Perempuan secara \\ Psikis}

Sebagai makhluk yang memiliki pikiran dan perasaan, Eva dalam novel Bidadari Terakhir merasa tersakiti secara pisikologis ia merasa sakit hati kepada makhluk yang namanya cowok yang membuat hidupnya seperti ini Hal ini dibuktikan pada data 4 dalam kutipan berikut.

"Dulu pernah. Terakhir pacaran juga apes. Cowok itu dimana-mana sama aja! Sama-sama brengsek. Maunya Cuma tidur doing sama aku. Setelah keinginan bejatnya tercapai, aku dicampakkan seperti nggak ada gunanya, Eva bercerita dengan dengan nafas memburu dengan mata terpendar." (Agnes, 2013:34)

Dari kutipan diatas jelas bahwa Eva sangat merasa dikecewakan dan dikhianati oleh pacarnya. Kepercayaan Eva kepada sosok lakilaki benar-benar hilang. Ia sempat putus asa dan menganggap bahwa semua laki-laki yang mendekati dirinya hanya menginginkan tubuhnya saja. Namu Eva dalam novel Bidadari Terakhir adalah wanita yang sangat kuat dan tegar. Secara psikologi ia tegar saat menghadapi orang-orang yang selalu menghina dirinya sebagai tuna susila. Sebab demi mendapatkan uang ia harus bekerja sebagai wanita penghibur. Dari kejadian tersebut Eva selalu mendapat cemohan dari orang-orang sekitarnya. Wanita dalam novel ini termasuk perempuan yang tegar.

Selain itu Eva harus menerima kenyataan bahwa ia mengidap penyakit sifilis. Penyakit tersebut sering membuat Eva sakitsakitan, dimana sederhananya wajah Eva terlihat sangat pucat dan tubuhnya semakin kurus bahkan parahnnya lagi ia harus kehilangan aktivitasnya akibat kakinya yang mengalami kelumpuhan. Hal ini dibuktikan pada data 5 dalam kutipan berikut.

"Ras, aku lumpuh ya? Tanya Eva tiba-tiba. 
Kamu nggak lumpuh. Kamu Cuma masih capek. Aku gendong ya."(Agnes, 2013:108)

Kutipan tersebut menjelaskan bahwa Eva mengidap penyakit sifilis. Penyakit tersebut diawali dengan penyakit kuning dan kondisi tubuh yang melemah, wajah semakin pucat serta mengalami kelumpuhan secara perlahan. Penyakit sifilis itu membuat Eva merasa lelah dan sakit. Seperti pada kutipan data 6 berikut ini.

"Nggak apa-apa, Ras! Bentar lagi aku akan sembuh kok....

Jangan keras kepala, Eva. Kamu harus ke dokter sekarang juga.

Nggak usah, Ras! Sergah Eva. Ini sudah biasa kok. Aku hanya butuh istirahat, Ras."(Agnes, 2013:106)

Kutipan tersebut menjelaskan bahwa semenjak Eva mengidap penyakit sifilis, ia tidak bisa kembali hidup normal seperti biasanya. Penyakit tersebut membuatnya tidak bisa kembali beraktifitas seperti biasanya. Namun dengan adanya penyakit tersebut tidak membuat Eva patah semangat, ia tidak ingin melihat ibunya ataupun Rasya menjadi sedih. Hal ini terdapat pada data 7 dalam kutipan berikut.

"kalau ada dua hal di dunia ini yang langsung dipenuhi Tuhan untuk kamu, kamu mau apa Rasya?

Hmmm, aku mau kamu cepat sembuh dan semangat kaya dulu lagi... kalau kamu?

Aku Cuma mau hidup lebih lama lagi supaya bisa mengenal kamu lebih jauh dan membahagiakan orang tua aku. Tapi kalau Tuhan nggak ngabulin saat ini, aku berharap dikehidupan mendatang aku bisa lakukan itu."( Agnes, 2013:116)

Kutipan tersebut menjelaskan bahwa meskipun Eva merasa kesakitan akan penyakit yang menyerang tubuhnya, namun ia tidak ingin melihat ibunya dan Rasya merasa sedih karena penyakit yang ia derita. Selain itu ia juga tetap berusaha tetap tegar dan masih berkeinginan untuk tetap membahagiakan ibunya. Disisi lain Eva tidak bisa menyembunyikan perasaan sedih untuk dirinya sendiri. Hal ini terdapat dalam data 8 pada kutipan berikut.

"Akhir-akhir ini selama di rumah sakit, Eva meminta ibunya untuk membawa buku dan pulpen. Entah mengapa dia jadi sering menulis, setiap ia menulis ia selalu menangis seperti dua hal yang menjadi rutinitas. Itulah yang dilakukan Eva setiap kali jari-jarinya menggoreskan pena di buku diarinya. Dia tumpahkan segala resah, gundah, dan gulana yag menggantung di hatinya. Gundah yang seperti enggan pergi, bahkan kian lama kian menggerogoti seluruh ruang dadanya."(Agnes, 2013:123)

Kutipan tersebut menjelaskan bahwa meskipun Eva bisa tegar menghadapi penyakitnya itu, namun ada saat dimana dia tetap akan merasa sedih dan rapuh. Penyakit tersebut telah mengubahnya dari gadis periang dan semangat menjadi gadis penyakitan yang kini tidak bisa berbuat apa-apa. Eva merasa penyakit tersebut akan membuat dia perlahanlahan semakin tak berdaya dan lama-kelamaan ia akan meninggal dunia.

Penyakit sifilis itu seakan merenggut segalanya dari sisi Eva. Namun Eva tidak berkecil hati dengan penyakitnya tersebut, ia tetap menjadi gadis yang periang dan semangat. Ia juga tak ingin melihat orang lain sedih dan terpukul karena penyakitnya tersebut, terlebih ibunya dan Rasya. Hal tersebut dapat dilihat pada data 9 dalam kutipan berikut.

"Eva... ibu tau ini sulit, tapi kali ini kondisi kamu sudah buruk. Tabib yang kemarin kesini sudah menyerah. Kamu pergi ke rumah sakit ya, ibu sudah hubungin keluarga yang lain. Mereka siap bantu. Ibu mohon, Eva. Ayah kamu juga sudah dapat pinjaman....

Eva tetap bergeming.

Maaf, udah bikin kalian susah dan repot saat ini, Eva tersedu.

Nggak ada yang susah dan repot, aku, ibu kamu, semua lakukan untuk kebaikan kamu. Kamu ikut ya ke rumah sakit....'(Agnes, 2013:107)

Kutipan diatas menjelaskan bahwa setelah divonis dengan penyakit sifilis, Eva merasa dirinya hanya sebagai beban untuk ibunya dan Rasya. Bahkan Eva merasa takut jika nanti ia membuat rasya terluka, sebab ia menyadari bahwa kebaikan yang diberikan oleh Rasya sudah menghadirkan perasaan cinta diantara mereka. Hal tersebut terdapat pada data 10 dalam kutipan berikut.

"Dia baik banget, bu. Aku benar-benar nggak pernah lihat orang sebaik itu dalam hidup aku selain bapak dan ibu.

Diam-diam gue masih mendengar ucapan Eva dari balik tirai.

Kamu harus sembuh makanya, jangan siasiakan pengorbanan nak Rasya....

Eva hanya terdiam, tidak menjawab. Tentu dia ingin sembuh. Tapi semua kehidupannya hanya berserah kepada Tuhan."(Agnes, 2013:)

Kutipan tersebut menjelaskan bahwa

Eva sangat menginginkan dirinya sembuh 
seperti dulu dan tidak membebanani orangorang yang ia sayang. Akan tetapi saat ini ia tidak bisa berbuat apa-apa. Melainkan menyimpan dalam-dalam perasaannya kepada Rasya. Karena ia tidak ingin Rasya kecewa, sebab dengan mengetahui penyakit sifilisnya saja Eva sudah merasa sangat malu kepada Rasya bahkan Rasya tidak perduli dengan hal itu, yang ia tahu hanyalah bagaimana ia bisa selalu bersama dengan Eva dan selalu bisa membantu Eva.

\subsubsection{Citra Perempuan Sebagai Anggota Keluarga}

\subsubsection{Citra Perempuan sebagai}

Ibu Rumah Tangga

Citra perempuan sebagai ibu rumah tangga yang akan dibahas adalah perempuan yang merupakan ibu dari tokoh utama. Perempuan sebagai ibu rumah tangga memiliki tanggung jawab yang besar, bukan hanya sebagai ibu rumah tangga, perempuan juga memiliki posisi yang penting sebagai pendidik dan membesarkan anak-anaknya.

\section{Tokoh Ibu Rasya}

Kasih sayang seorang ibu dalam merawat, membimbing dan menasehati anaknya untuk menjadi anak yang baik yang dan berprestasi di tunjukkan oleh ibu Rasya pada data 11 dalam kutipan berikut.

"Rasya... buruan turun! Kita sarapan samasama, sayang. Suara mama melengking dari ruang bawah.” (Agnes, 2013:4)

Kutipan tersebut menggambarkan bahwa kasih sayang yang ditunjukkan oleh ibu Rasya kepada anaknya sangat besar bahkan ia tidak pernah lupa mengingatkan anak-anaknya untuk sarapan pagi sebelum beraktifitas. Kasih sayang dan nasehat ibu Rasya juga di tujukan pada data 12 dalam kutipan berikut.

"kakak kamu itukan sudah kelas tiga. Sebentar lagi Ujian Nasional. Belajarnya yang bener ya soalnya nilai tingkat kelulusan mama denger udah diatas sekian berapa gitu..., penjelasan mama panjang lebar.” (Agnes, 2013:7)

Pada kutipan tersebut jelas digambarkan bahwa ibu Rasya sangat menyayangi anakanaknya ia selalu mengingatkan tugas dan kewajiban anaknya sebagai seorang siswa untuk terus belajar, terlebih lagi mengingat anaknya akan menghadapi Ujian Nasional untuk menyelesaikan pendidikannya pada jenjang Sekolah Menengah Atas (SMA).

\section{Tokoh Ibu Eva}

Seperti kasih sayang yang diberikan oleh ibu Rasya kepada anak-anaknya, ibu Eva juga senantiasa menemani anaknya dalam keadaan apapun. Saat Eva menderita penyakit sifilis ibunya tak pernah putusnya memberikan semangat kepada Eva. Eva adalah putri satusatunya sehingga ia amat sayang dan takut kehilangan Eva. Hal ini terdapat pada data 13 dalam kutipan berikut.

"Bu..., Eva membuka taut bibirnya.

Iya, Eva...Ada apa, nak ? ucap perempuan itu lirih.

Maafin Eva ya, Eva udah ngerepotin ibu. Bapak mana, Bu?

Sekali lagi ibunya mengusap kepala Eva, lalu melabuhkan sebuah kecupan di keningnya. Damai, Eva menyesap damai itu perlahan. Dia memejamkan matanya. Jangan bicara seperti itu, Eva. Tidak ada seorang ibu pun di dunia ini yang merasa direpotkan oleh anaknya sendiri.

Bapak kamu lagi beli makan untuk makan siang."(Agnes, 2013:138)

Kutipan tersebut menjelaskan bahwa ibu Eva sangat menyayangi anaknya. Ia tidak ingin kehilangan Eva, terlebih lagi Eva adalah putri satu-satunya. Ia berpikiran anak gadisnya, cahaya matannya yang mungkin akan kehilangan segalanya dan tidak bisa lagi bangkit dari tempat tidur serta harus kehilangan harihari penuh warna yang dijalaninya. Namun apapun itu, asal dia masih bisa memandang wajah bersih putrinya tanpa polesan. Ia akan sangat tidak sanggup melihat putrinya yang seperti itu. Ia harus selalu merasa sedih jika memikirkan putrid satu-satunya itu harus pergi meninggalkan dunia ini untuk selamanya nanti. Namun disisi lain, ibu Eva tidak ingin memperlihatkan kesedihannya kepada putrinya itu. Ia hanya ingin melihat putrinya bahagia tanpa melihat kesedihannya.

\subsubsection{Citra Perempuan sebagai \\ Anak}

Citra perempuan sebagai anak dalam novel ini menggambarkan bagaimana seorang anak perempuan itu kepada kedua orang tuanya. Tokoh Eva sangatlah dekat dengan ibunya karena semenjak ayahnya meninggal ia hanya tinggal bersama ibunya. Namun kehidupannya mulai berubah sejak ibunya menikah lagi dengan ayah tirinya yang setiap hari menghabiskan uang untuk berjudi. Bahkan ia harus bekerja semenjak ibunya jatuh sakit akibat terkena tumor ringan demi memenuhi 
kebutuhan hidupnya dan ia harus bekerja mendapatkan uang untuk biaya oprasi dengan pendidikannya yang minim hanya lulusan Smp sehingga ia bekerja sebagai wanita penghibur. Hal ini terdapat pada data 14 dari kutipan berikut.

"Ya, nasib jadi orang miskin. Tiba-tiba nyokapku kena penyakit. Ada benjolan diperut dia yang makin hari makin besar. Kemarin udah dibawa kepuskesmas, kata orang puskesmas sih tumor ringan dan butuh oprasi. Tau sendiri Negara kita, apa-apa butuh duit. Nyokap mesti cepat-cepat di oprasi makanya aku butuh duit. Malah minggu ini lagi apes, nggak ada pelanggan sama sekali....”(Agnes, 2013:23)

kutipan tersebut menjelaskan bahwa ibu Eva sudah tidak sehat seperti dulu lagi. Bahkan ayah tirinya sama sekali tidak peduli dengan keadaan ibunya sehingga Eva harus berjuang sendiri mencari biaya oprasi agar ibunya cepat sembuh untuk itu ia harus membayar biaya oprasi sebesar 1,7 juta rupiah. Bahkan Eva sudah tidak peduli dengan kelakuan ayahnya yang selalu menjadi beban untuk ibunya terlebih lagi ibunya harus meminjam uang pada tetangganya agar bisa berobat ke puskesmas sebelum Eva mendapatkan uang.

Sebagai seorang anak Eva ingin sekali membahagiakan ibunya semenjak ayah kandungnya meninggal. Bahkan ketika ibunya menikah lagi Eva tidak tega melihat ibunya menderita sebab ayah tirinya tak pernah peduli pada kelurga bahkan kepada ibunya yang sedang sakit. Akan tetapi tidak menyerah begitu saja ia tetap ingin membantu ibunya meskipun ia juga terkena penyakit sifilis. Hal tersebut dapat dilihat pada data 15 dalam kutipan berikut.

"Namanya juga jualan, kadang laku kadang nggak laku. Apes banget gue hari ini"(Agnes, 2013:21)

Kutipan tersebut menjelaskan bahwa Eva ingin sekali membantu ibunya. Setidaknya ia bisa membantu biaya oprasi yang dibutuhkan oleh ibunya agar segera pulih dari penyakit tumor jinak yang dialaminya.

\subsubsection{Citra Perempuan dalam Masyarakat}

\subsubsection{Hubungan Antarpribadi}

Hubungan antar pribadi dapat dilihat dari hubungan tokoh Eva dengan tokoh-tokoh lainnya. Dalam novel "Bidadari Terakhir" mempersentasikan hubungan antar pribadi yakni perempuan dan perempuan lainnya dan hubungan perempuan dan pria lainnya.

\section{Perempuan dengan perempuan lainnya}

Hubungan Eva dan Angel sangat baik. Angel adalah adik dari Rasya remaja SMA yang selalu ada untuk Eva. Bahkan saat Eva membutuhkan uang untuk biaya rumah sakit Angel membantunya meskipun mereka tidak pernah saling kenal. Hal ini terdapat pada data 16 dalam kutipan berikut.

"Angel beranjak pergi dan beberapa menit kemudian dia kembali dengan celengan di tangannya. Kakak pecahin aja celengan Angel. Ini udah setahun Angel kumpulin, mudahmudahan cukup dan ini ada uang Angel nggak seberapa siapa tau berguna buat bantu-bantu..., ujarnya sembari menyerahkan celengan ke tangan gue"(Agnes, 2013:113)

Kutipan tersebut menjelaskan bahwa Angel adalah anak yang baik dan selalu memberi semangat kepada Rasya untuk membantu Eva. Selain itu Angel sangat bangga kepada Rasya karena ia memiliki sifat yang baik selalu menolong orang lain yang membutuhkan bantuan. Hal ini terdapat dalam data 17 pada kutipan berikut.

"Kakak bikin aku bangga sama sifat pahlawan kakak semoga pacar kakak cepat sembuh ya...." (Agnes, 2013:113)

Kutipan tersebut jelas menggambarkan bahwa Angel sangat salut dan bangga kepada kakaknya karena Rasya merupakan kakak yang baik dan memiliki jiwa sosial yang tinggi.

\section{Hubungan Eva dengan Pria Lain}

Hubungan antara Eva dan Rasya sebelumnya biasa-biasa saja. Mereka berdua tidak sengaja bertemu di tempat hiburan malam dimana Eva bekerja, seiring berjalannya waktu semakin banyak hal yang terjadi diantara mereka seperti Eva membutukan uang sampai ia terkena penyakit sifilis. Semua itu memumbuhkan rasa cinta dan rasa nyaman diantara keduanya. Akan tetapi mereka harus merasakan kesedihan yang mendalam untuk kehilangan satu sama lain karena penyakit yang diderita oleh Eva merenggut seluruh hidupnya, harapannya, dan juga cintanya. Hal tersebut terdapat dalam data 18 pada kutipan berikut.

"setetes air mata jatuh di pipinya. Hanya setetes. Untuk selanjutnya gue rasakan tubuh Eva semakin pucat, sesaat sesudahnya jari-jarinya kembali bergerak. Tampaknya ia masih bisa mendengar apa yang gue katakan, meski hanya bisa membalasnya isyarat mata. Gue mengusap setitik air mata yang jatuh di pipinya. Tetes air 
mata terakhir, setelahnya Eva kembali terpejam (Agnes, 2013:145)"

Kutipan tersebut menjelaskan bahwa sebelum Eva pergi meninggalkan semuanya dengan rasa sakit yang tidak sanggup ia rasakan ia masih bisa mendengarkan orang yang berda di sampingnya. Namu untuk mengatakan sesuatu ia sudah tidak sanggup lagi. Hal ini terdapat pada data 19 dalam kutipan berikut.

"Tangan kanannya menarik tangan gue. Lalu hal terakhir yang Eva lakukan membuat gue begitu sedih. Dia melukiskan sebuah lambang hati dengan jarinya di tangan gue. Perlahan, sebuah goresan tak berbekas berbentuk love. Saat itulah dia mengangis dan gue pun menangis.

Eva kalau kamu mau pergi... aku ikhlas, aku janji bakal kuat....

Air mata Eva terjatuh, saat itulah ia menutup matanya dengan tersenyum.”(Agnes, 2013:146).

Kutipan tersebut menjelaskan bahwa Eva pergi meninggalkan dunia ini dengan tenang ia berhasil melewati rasa sakitnya dan senyum indah terukir di bibirnya sesaat setelah ia melukiskan gambaran hati di tangan Rasya yang mengutarakan perasaanya selama ini bahwa ia juga mencintai Rasya.

\subsubsection{Hubungan Pribadi dengan Masyarakat}

Dalam Novel Bidadari Terakhir hubungan pribadi dengan masyarakat, tokoh utama Eva berhubungan dengan masyarakat di lingkungan tempat tinggalnya. Di tempat tinggalnya Eva selalu mendapat cemohan dan hujatan dari orang-orang sekitar karena pekerjaannya sebagai wanita tuna susila. Hal ini terdapat pada data 20 dalam kutipan berikut.

"Ngapain minta maaf, Ras? Itu bukan salah kamu kok. Emang udah nasib aku terlahir dari keluarga miskin, melarat, hina, dan... kata orang... lonte. Air mata tangis Eva terjatuh saat dia mengeluarkan kata terakhir dari kalimatnya. Dia buru-buru menyeka air matanya"(Agnes, 2013:35).

Kutipan tersebut menjelaskan bahwa hubungan Eva dengan masyarakat sekitar tidak begitu baik. Sebab ia selalu mendapat cemohan dan hinaan dari orang-orang sekitar tempat tinggalnya. Namun hal itu tidak menurunkan semangat Eva bekerja karena yang ada dalam pikirannya adalah bagaiman ia mendapatkan uang dengan pendidikan yang minim hanya tamatan SMP dan tidak memiliki keterampilan apa-apa selain bekerja di tempat hiburan malam, karena yang terpenting buat Eva adalah kesembuhan ibunya dari pada cemohan dari orang-orang tersebut.

\subsubsection{Citra Perempuan dalam \\ Bidang Pendidikan}

Dalam novel Bidadari Terakhir karya Agnes Davonar digambarkan pula perempuan dalam bidang pendidikan. Dimana perempuan mampu bersaing sebagai perempuan yang cerdas dan mampu menunjukkan dirinya sebagai ketua tim dalam sebuah kegiatan antar sekolah. Hal ini dapat dilihat pada data 22 dalam kutipan berikut.

Kak. Maaf ya ganggu. Aku mau minta tolong dong. Selama liburan ini aku lagi persiapan buat cerdas cermat bulan depan. Aku kan kepilih jadi ketua, karena anak kelas tiga kan udah nggak bisa. Kak Rasya mau nemenin aku buat cari beberapa referensi? (Agnes, 2013:97).

Hal serupa juga terdapat pada data 23 dalam kutipan berikut.

"Sms dari Maria cukup panjang. Sebagai orang yang pernah menjadi ketua tim, gue tahu kesibukan Maria untuk mempersiapkan materi dan referensi yang kadang tidak ada di perpustakaan sekolah. Akhirnya setelah memilih tempat yang telah disepakati, gue menemani maria ke beberapa toko buku. Hanya Maria yang sibuk memilih buku yang dia butuhkan, sementara gue lebih memilih melihatlihat komik" (Agnes, 2013:97).

Hal tersebut jelas digambarkan bahwa perempuan juga mampu menunjukkan eksistensinya dalam bidang pendidikan melalui kegiatan yang ia ikuti dan setiap prestasi yang ia dapatkan seperti digambarkan dalam kutipan 21 dan 22 diatas dimana Maria adalah tokoh perempuan lain dalam novel bidadari terakhir karya Agnes Davonar yang berhasil terpilih penjadi ketua tim cerdas cermat dalam kegiatan antar sekolah mewakili sekolah tempat ia belajar.

\subsubsection{Citra Perempuan dalam \\ Bidang Ekonomi}

Dalam novel Bidadari Terakhir karya Agnes Davonar citra perempuan dalam bidang ekonomi jelas digambarkan bahwa perempuan sangat penting perannya dalam kehidupan sehari-hari. Ketika ibunya jatuh sakit, Eva harus bekerja keras menghidupi keluarganya serta menggantikan posisi ayahnya sebagai kepala rumah tangga. Menjadi tulang punggung 
keluarga tidaklah mudah bagi Eva yang tidak memiliki keterampilan apa-apa sebab ia hanya tamatan sekolah menengah pertama (SMP). Semenjak ibunya menikah lagi dengan laki-laki lain semenjak ayahnya meninggal, Eva tidak merasa beban dalam kehidupan rumah berkurang karena telah memiliki ayah sambung yang menggantikan posisi ayahnya sebagai kepala rumah tangga. Justru sebaliknya ia harus menggantikan posisi ayahnya bekerja mencari nafkah karena laki-laki yang dinikahi oleh ibunya sama sekali tidak meringankan beban tetapi malah menambah beban hidupnya. Bukan hanya kebutuhan rumah tangga dan biaya hidup, Eva harus mencari uang untuk biaya pengobatan ibunya yang terkena tumor ringan di bagian perut dan harus di oprasi. Hal tersebut dapat di lihat pada data 21 dalam kutipan berikut.

"kamu jangan bercanda, Ras. Uang 1,7 juta itu nggak sedikit. Dia menatap ujung sepatunya.

$\mathrm{Aku}$ sih udah sering digombalin sama pelanggan tapi kalau digombalin sama brodong baru kali ini, ledek dia" (Agnes, 2013:25).

Kutipan di atas menjelaskan bahwa Eva sangat membutuhkan uang untuk biaya oprasi bahkan ia tidak tahu harus bekerja apa lagi untuk mendapatkan uang karena uang yang ia dapatkan dari hasil pekerjaannya tidaklah cukup untuk mebayar biaya oprasi sehingga ia menerima bantuan dari Rasya remaja SMA yang tidak sengaja ia temui di warung dekat diskotik tempatnya bekerja.

\subsection{Nilai Pendidikan dalam Citra \\ Perempuan pada Novel Bidadari \\ Terakhir karya Agnes Davonar \\ Citra Perempuan dalam novel Bidadari} Terakhir karya Agnes Davonar juga memiliki nilai positif dalam bentuk pendidikan moral yang dapat dijadikan sebagai pedoman yaitu nilai pendidikan moral suka menolong, keteguhan dan komitmen, kerjasama, kepedulian dan empati, serta tanggung jawab. Hal ini dapat dilihat pada kutipan berikut.

\subsubsection{Suka Menolong}

Suka menolong adalah kebiasaan membantu orang lain yang mengalami kesulitan dalam bentuk sekecil apapun untuk selalu mengulurkan tangan memberikan sesuatu yang mereka butuhkan. Seperti dalam novel Bidadari Terakhir Karya Agnes Davonar, suka menolong digambarkan oleh tokoh Angel dalam kutipan berikut.
"Angel beranjak pergi dan beberapa menit kemudian dia kembali dengan celengan di tangannya. Kakak pecahin aja celengan Angel. Ini udah setahun Angel kumpulin, mudahmudahan cukup dan ini ada uang Angel nggak seberapa siapa tau berguna buat bantu-bantu..., ujarnya sembari menyerahkan celengan ke tangan gue"(Agnes, 2013:113)

Pada kutipan tersebut nilai pendidikan moral suka menolong jelas digambarkan oleh tokoh Angel bahwa ia memberikan uang yang ditabung di celengannya selama ini kepada kakaknya untuk menolong kakaknya yang sedang membutuhkan uang.

\subsubsection{Keteguhan Dan Komitmen}

Keteguhan dan komitmen dalam hal ini adalah janji yang dipegang teguh terhadap keyakinan dan memberi dukungan serta setia kepada keluarga dan teman. Keteguhan hati juga dapat membuat seseorang mencapai citacitanya. Keteguhan dan komitmen pada Citra Perempuan dalam novel Bidadari Terakhir karya Agnes Davonar digambarkan oleh tokoh Rasya dalam komitmennya pada diri sendiri dan kedua orang tuanya. Hal ini dapat dilihat dalam kutipan berikut.

"Demi membanggakan Mama dan Papa, gue selalu berusaha memberikan yang terbaik buat mereka termasuk dalam hal pendidikan. Karena gue punya cita-cita, kelak bakal ikutin jejak mereka jadi PNS, atau paling mepet jadi Polisi atau Tentara."(Agnes, 2013:3)

Kutipan tersebut menggambarkan bahwa keteguhan dan komitmen seorang anak pada diri sendiri dan kedua orang tuanya sangat jelas digambarkan oleh tokoh Rasya. Ia ingin mengikuti jejak kedua orang tuanya menjadi PNS atau mengabdi pada Negara menjadi Polisi atau Tentara.

\subsubsection{Kepedulian dan Empati}

Kepedulian dan empati didasarkan pada pemahaman perasaan diri sendiri dan memahami orang lain. Kepedulian dan empati adalah cara kita menanggapi perasaan, pikiran, dan pengalaman orang lain karena kita secara alami merasakan kepedulian terahadap sesama agar berupaya mengenali pribadi orang lain dan keinginan membantu orang lain yang sedang dalam keadaan susah. Melalui empati, seseorang mengenali rasa kemanusiaan terhadap diri sendiri ataupun orang lain. Hal tersebut dapat dilihat dalam percakapan Eva dan Rasya dalam kutipan berikut 
“Ada masalah apa sih, mbak? Tanya gue. Dia menatap gue dari ujung kaki sampai kepala.

Kamu umur berapa sih?

Masih 17 tahun, mbak.

Astaga masih brondong. Belum tau dong dunia orang dewasa.

Kata siapa? Yaelah, mbak. Yang namanya masalah, nggak brondong, anak-anak sampai dewasa semua juga ngerasain, nggak mandang umur, kok

Kayanya kamu bener-bener beda ya sama cowok-cowok yang datang kesini? Biasanya mereka cuma cari kesenangan tanpa mau peduli apa masalah yang terjadi pada siapa saja.

Nggak semua cowok kaya gitu kok, mbak, pasti ada kok yang baik. Namanya juga kehidupan. Dia setuju dengan pernyataan gue dan langsung menjelaskan masalah dia.

Mungkin aja, aku lagi butuh duit....

Maaf kalau boleh tau, butuh duit buat apa, mbak?

Tiba-tiba nyokapku kena penyakit. Ada benjolan di perut dia yang makin hari makin besar. Kemarin udah dibawa ke puskesmas, kata orang puskesmas sih tumor ringan dan butuh oprasi.

Mendengar bicara dia yang ceplas-ceplos, entah mengapa gue merasa iba dan merasa dia tidak sedang bercanda. Apalagi mengarang cerita agar gue membantu dia”. (Agnes, 2013: 22-23)

Kutipan di atas bahwa rasa kepedulian dan empati jelas digambarkan oleh tokoh Rasya yang tidak sengaja bertemu Eva di depan diskotik dan menceritakan pada Rasya masalah yang dihadapinya bahwa ia sedang membutuhkan uang untuk biaya oprasi sang ibu, mendengar cerita yang di lontarkan oleh Eva. Rasya merasa iba dengan kondisi Eva saat.

\subsubsection{Tanggung jawab}

Tanggung jawab adalah perilaku yang menentukan seseorang bereaksi terhadap situasi setiap hari yang memerlukan beberapa keputusan. Hal tersebut dilakukan oleh Eva terhadap keluarga dan orang tuanya sehingga ia mengorbankan dirinya untuk bekrja agar keluarganya bisa bertahan hidup dan ibunya bisa mendapat pengobatan yang maksimal atas penyakit tumor ringan yang dideritanya. Hal tersebut dapat di lihat dalam kutipan berikut.

"Asal kamu tahu, Ras. Aku nggak pengin kerja kaya gini. Tapi buat apa mimpi tinggi-tinggi sementara ada perut-perut kelaparan yang harus aku kasih makan. Dan sekarang ada ibuku yang harus segera ditolong." (Agnes, 2013:36)
Dari kutipan berikut jelas digambarkan bahwa rasa tanggung jawab Eva terhadap keluarga dan orang tuanya sangat besar sehingga membuat ia harus bekerja dengan mengorbankan dirinya hingga terkena penyakit dan di hina oleh orang-orang sekitarnya.

\section{PENUTUP}

\subsection{Kesimpulan}

Berdasarkan pembahasan hasil penelitian, dapat disimpulkan bahwa citra perempuan yang terdapat dalam novel Bidadari Terakhir karya Agnes Davonar mencakup empat komponen citra perempuan pertama citra perempuan sebagai individu yang meliputi citra perempuan secara fisik dan psikis, kedua citra perempuan sebagai anggota keluarga yang mencerminkan citra perempuan sebagai seorang anak dan citra perempuan sebagai ibu rumah tangga, ketiga citra perempuan dalam masyarakat berkaitan dengan hubungan antarpribadi dan pribadi dengan masyarakat, dan keempat citra perempuan dalam bidang pendidikan dan kelima citra perempuan dalam bidang ekonomi.

Citra perempuan sebagai individu dilihat dari aspek fisik dan psikisnya, dari hasil penelitian disimpulkan bahwa tokoh utama Eva adalah sorang anak yang selalu semangat dan rela berkorban demi keluarganya. Selain kajian citra perempuan sebagai individu, citra perempuan yang terdapat dalam novel Bidadari Terakhir karya Agnes Davonar yaitu citra soaial perempuan yang digambarkan oleh tokoh Angel dalam membantu Eva dengan memberikan uang tabungannya kepada Rasya untuk mencukupi biaya pengobatan yang di butuhkan oleh Eva. Dan citra perempuan dari aspek pendidikan juga digambarkan oleh tokoh Maria yang berhasil terpilih menjadi ketua tim lomba cerdas cermat antar sekolah untuk mendampingi temantemannya hal tersebut menunjukkan bahwa perempuan mampu menunjukkan dirinya dalam dunia pendidikan dan lingkungannya dari beberapa aspek citra perempuan tersebut dapat ditarik kesimpulan bahwa perempuan dalam novel tersebut telah memposisikan dirinya sebagaimana mestinya. Ia harus memperhatikan lingkungan keluarganya, perempuan harus sadar akan tanggung jawabnya apakah ia seorang ibu, sebagai anak, atau sebagai istri. Selain itu, selain dalam lingkungan keluarga tokoh utama citra perempuan dalam novel Bidadari Terakhir karya Agnes Davonar juga memperlihatkan bagaimana ia bersikap terhadap masyarakat. 
Citra perempuan yang terakhir yaitu dari kajian citra perempuan dalam bidang ekonomi dalam novel Bidadari Terakhir karya Agnes Davonar dapat di tarik kesimpulan bahwa tokoh utama dalam novel tersebut adalah sosok perempuan yang kuat, mandiri, dan bekerja keras. Ia rela bekerja sebagai wanita penghibur demi mendapatkan uang untuk memenuhi kebutuhan hidup keluarga dan biaya pengobatan untuk sang ibu yang mengidap tumor ringan pada bagian perut.

\subsection{Saran}

Berdasarkan hasil penelitian, yang menjadi saran peneliti adalah:

a. Agar penelitian mengenai citra perempuan dalam novel ini dapat di jadikan sebagai bahan pembelajaran atau pedoman hidup bagi kita dalam melaksanakan aktivitas keseharian atau untuk kepentingan dalam interaksi sosial.

b. Agar pembaca dapat memberikan masukan terhadap hasil penelitian ini

c. Untuk kepentingan pengajaran sastra, hasil penelitian ini dapat dijadikan sebagi bahan referensi untuk pengajaran prosa di sekolah-sekolah maupun di perguruan tinggi.

d. Semua nilai yang terkandung dalam novel Bidadari Terakhir karya Agnes Davonar dapat dijadikan referensi penelitian bagi peneliti lainnya dalam melakukan penelitian selanjutnya.

\section{DAFTAR PUSTKA}

Davonar, Agnes. 2013. Bidadari Terakhir. Jakarta: Intibook Publisher.

Djajanegara, Soenarjati. 2003. Kritik Sastra Feminis Sebuah Pengantar. Jakarta: Gramedia Pustaka Utama.

Djajanegara, Soenarjati. 2010. Bahasa, Sastra, dan Wanita. Jakarta: Penaku

Jabrohim. 2014. Teori Penelitian Sastra. Yogyakarta: Pustaka Pelajar.

Nurgiyantoro, Burhan. 2015. Teori Pengkajian Fiksi. Yogyakarta: Gajah Mada University Perss.

Pusat Bahasa Departemen Pendidikan Nasional. 2002. Kamus Besar Bahasa Indonesia Edisi Ketiga. Jakarta: Balai Pustaka.

Sugihastuti dan Itsna Hadi Setiawan. 2010. Gender dan Inferioritas Perempuan:Praktik Kritik Sastra Feminis. Yogyakarta: Pustaka Pelajar
Sugihastuti dan Suharto. 2015. Kritik Sastra Feminis Teori dan Aplikasinya. Yogyakarta: Pustaka Pelajar.

Sugihastuti. 2000. Wanita Di Mata Wanita, Perspektif Sajak-Sajak Toety Heraty. Penerbit Nuansa

Sutana, Dwi. 2015. Karya Sastra dalam Harian Haluan Kepri. Tanjung Pinang Barat: Kantor Bahasa Kepulauan Riau.

Tarigan, Henry Guntur. 1995. Dasar-dasar Pisiko Sastra. Bandung: Angkasa

Udu, Sumiman. 2009. Perempuan dalam Kabanti Tinjauan Sosiofeminis. Yogyakarta: Diandra.

Wellek, Rene dan Warren Austin. 2016: Teori Kesusastraan. Jakarta: Gramedia IKAPI.

Wicaksono, Andri. 2014. Pengkajian Prosa

Fiksi. Yogyakarta: Garudhawaca. 